\title{
DIALOGUE
}

Canadian Philosophical Review/Revue canadienne de philosophie

Vol. XLVII, No. 3-4 Summer-Fall/Été-Automne 2008

\section{Obituary/Notice nécrologique}

Venant Cauchy in memoriam

YVON GAUTHIER 419

Identité personnelle et culturelle dans une perspective de mondialisation VENANT CAUCHY 421

\section{Articles}

Strategic Reliabilism and the Replacement Thesis in Epistemology ANDREI A. BUCKAREFF 425

Hybrid Varieties of Pleasure and the Complex Case of the

Pleasures of Learning in Plato's Philebus

$$
\text { CRISTINA IONESCU } 439
$$

La Critique de la raison pure face aux scepticismes cartésien, baylien et humien PLINIO JUNQUEIRA SMITH 463

Logical Space and the Space of Sight: The Relevance of Wittgenstein's

Arguments to Recent Issues in the Philosophy of Mind LUDOVIC SOUTIF 501

Foucault, Weber et l'histoire du sujet économique PHILIPPE STEINER 537

A Pragmatic Phenomenalist Account of Knowledge BYEONG D. LEE 565

The Glass Shatters and Ducks Turn into Rabbits: Bad Faith and Moral Luck MATTHEW KING 583

Hume's Impression of Succession (Time) JON CHARLES MILLER 603

Williamson and the Argument from Luminosity P. X. MONAGHAN 619 
La conception du raisonnement de John Broome : «Que nous exprimons-nous lorsque nous raisonnons?» JOSÉE BRUNET 633

\section{Interventions/Discussions}

The Rump Parliament of Modern Academic Philosophy DOUGLAS MANN 663

A Note on McDowell's Response to the Fineness of Grain Argument ANDRE J. ABATH 677

\section{Book Reviews/Comptes rendus}

JOSIANE BOULAD-AYOUB et PAULE-MONIQUE VERNES, La révolution cartésienne CHRISTIAN LEDUC 687

FRANÇOIS DUCHESNEAU et JÉRÉMIE GRIARD, Leibniz selon les Nouveaux essais sur l'entendement humain MOGENS LÆRKE 690

LORRAine SMith Pangle, The Political Philosophy of Benjamin Franklin SHANE RALSTON 694

ROBERT C. SOlOMOn, True to Our Feelings: What Our Emotions Are Really Telling Us MICHEL JEAN 696

DAVID CORFIELD, Towards a Philosophy of Real Mathematics YVON GAUTHIER 700

GEORGES LEROUX, Dialogue, éthique, culture religieuse : arguments pour un programme NAÏMA HAMROUNI 702

KENT A. PEACOCK and ANDREW D. IRVINE, editors, Mistakes of Reason: Essays in Honour of John Woods RAMSEY MCNABB 705 JEFF JORDAN, Pascal's Wager: Pragmatic Arguments and Belief in God JACK MACINTOSH 708

Books Received/Livres reçus 711

Index/Sommaire/Volume XLVII/2008 713 